\title{
FUNCTIONS OF THE INITIATIVE, REFERENDUM AND RECALL
}

\author{
By Jonathan Bourne, Jr.,
} United States Senator from Oregon.

Briefly summarized, the functions of the initiative and referendum are:

To restore the sovereignty of the people.

To educate and develop the people.

To secure legislation for the general welfare.

To prevent legislation against the general welfare.

To eliminate the legislative blackmailer.

To make our legislative bodies truly representative.

I will discuss each of these in the order mentioned.

The chief function of the initiative and referendum is to restore the absolute sovereignty of the people-to make this in fact as well as in name, a government of, for and by the people. The word "sovereignty" conveys the idea of supreme rulership and we have taken pride in flattering ourselves that the American people enjoy the power of self-government. And so they do, in theory, but I shall undertake to demonstrate that they do not in practice, except in the few rare instances when, after suffering a long series of abuses, they arise, assert their rights and temporarily overthrow their political dictators.

The citizens of every state have seen legislature after legislature enact laws for the special advantage of a few and refuse to enact laws for the welfare of the many. Under the convention system of nominations, which has been universal until the last few years, slates of delegates were selected by men who commercialized politics, and the great masses of the people, unacquainted with political manipulation or too honest to resort to it, had no recourse but to ratify the slate. These specially selected delegates nominated candidates for legislative, judicial and executive offices in accordance with the desire of the boss. The same methods having been pursued in each political party, the voter was given a choice between two sets of candidates each under obligations to, and, therefore, responsible to, the manager of the party machine. Under this system, 
cities, counties and states have long been ruled and the people deluded themselves with the pleasing assumption that this was "self-government."

Nay, more. This rulership by self-constituted dictators extended to national affairs, and through the misuse of federal patronage, aided by excessive representation in some of the states, control of national conventions has been secured and the will of the people has been ignored. Such rulership will exist in any state not having a direct primary guarded by an efficient corrupt practices act, and it will continue to exist in national affairs until, through the general adoption of a presidential primary, the people obtain the power to select the party candidates free from the dictation of managers of federal machines. Our boasted "sovereignty of the people" has been a myth, a delusion and a snare - an empty phrase serving chiefly to delay the ultimate assertion of the rights of citizenship.

Realization that legislatures were habitually misrepresentative and that public servants were selected by private interests has finally inspired the people of this country with new hopes, has aroused them to higher ideals and brought them a "new birth of freedom," so that to-day the fight for the new independence is waged in every state and in the nation at large.

\section{Initiative and Referendum Foundation of Popular Government}

It is the battle for popular government, at the foundation of which lies the initiative and referendum-the power of the people to make laws. Once this power is secured the other popular government features will be added, until conventions, the ready instrumentality of the political dictator, will be abolished and the direct primary, corrupt practices act and recall will be established. Then may we speak truly of the "sovereignty of the people," for then will exist their power to make or unmake laws, to select candidates and elect public servants, to dismiss from service any elected officer who proves unfaithful, incompetent or otherwise unsatisfactory. Nothing short of this can fulfil the idea of supreme rulership which the word "sovereign" conveys.

But let us not be deceived as to the extent and manner of the exercise of this power. It is not proposed that the people shall act directly in all the intricate details of legislation or that legislatures shall be abolished or made needless. Such has not been the experi- 
ence in my own state, Oregon, where the intitiative and referendum have been most employed. At the last general election the people of Oregon voted upon thirty-two measures, the largest number ever submitted at one election. Of these measures, eleven were constitutional amendments, of which four were adopted and seven rejectea. Of the twenty-one bills submitted, only five were enacted and sixteen rejected. The result of the direct vote was nine measures adopted. The Oregon Legislature held a forty-day session last January, considered seven hundred and twenty-five bills and two hundred and thirty-five resolutions and memorials. Two hundred and seventy-five of the bills were enacted. Therefore, the extent of substitution of direct legislation is indicated by the ratio of nine to two hundred and seventy-five. This is not exactly "abandonment" of the representative system. Yet Oregon enjoys popular government and the people are sovereign, for they had the power under the referendum to defeat almost any one of those two hundred and seventy-five legislative acts. They have the power to enact any measure the legislature failed to pass.

It is a very general opinion that the American people are afflicted with too much legislation, but, if this be true, the fault lies not with the initiative, as I have just shown. Neither can the initiative be charged with whatever evils may have arisen from hasty or illconsidered laws. The fact is that laws enacted by the people are more carefully prepared, more widely discussed, and more thoroughly considered than are the acts of a legislature. A bill or proposed constitutional amendment submitted under the initiative must be filed with the secretary of state not less than four months before the election. Prior to that time the measure secures publicity through the fact that it must be circulated for the signatures of eight per cent of the voters. After the bills have been filed the promoters and opponents thereof may file arguments for or against. It is made the duty of the secretary of state to have a full copy of the title and text of each measure, together with the arguments for and against, printed in a pamphlet, a copy of which must be mailed to every registered voter not less than fifty-five days prior to election. The title of a bill appears in the publicity pamphlet exactly as it will appear upon the ballot. In this way the voter secures the best possible information regarding the provisions of the bills, their merits or defects, and the reason why they should or should not be enacted. 
No such opportunity for the study of measures is afforded members of a legislature. The Oregon Legislature, for instance, is in session only forty days and members secure printed copies of the bills introduced no sooner than the end of the first week. Very frequently important bills are introduced after the middle of the session and the members have copies of these before them not more than twenty days. Amendments are frequent, and sometimes these are made as late as the day on which the bill is passed, so that legislators frequently vote upon bills without knowing their real effect.

We had a conclusive demonstration of this in the Oregon Legislature of 1903, when the legislature repealed a statute which allowed every householder a tax exemption of household goods to the value of $\$ 300$. After the legislature adjourned members were astonished to learn that they had repealed such a law, and, at a special session, called within a year, this statute was re-enacted by an overwhelming vote. Four months of public discussion would have disclosed the nature of the bill and would have prevented action not intended.

\section{No Hasty or Unwise Action}

In the exercise of this sovereign power there are other circumstances that guard against unwise action. One argument often used against the initiative is that a measure submitted under it is not susceptible of amendment after it has been filed in the office of the secretary of state. Instead of being cause for criticism, this is reason for commendation, for experience has shown that one of the common methods by which vicious legislation is secured is to introduce a harmless or beneficial bill and let it secure a favorable report from a legislative committee, but with a slight amendment inserted therein which entirely changes its character or effect in some important particular, thereby serving some selfish interest. When it is known that a bill must be enacted or rejected exactly as drawn, the framers of the measure will spend weeks and months in studying the subject and drafting the bill in order to have it free from unsatisfactory features.

In actual practice in Oregon almost every proposed bill is submitted to a considerable number of men for criticism and suggestions before its final form is determined upon. The original draft undergoes many amendments, and these are more carefully considered than would be the case if the bill were before a legislature. Know- 
ing that the bill will be subjected to the closest scrutiny of all the people for four months, the framers of the bill desiring its passage naturally endeavor to remove every reasonable objection, to make all its provisions perfectly clear, and especially to remove every indication of bad faith. A bill to which there are many serious objections would stand little chance of adoption by a popular vote. When thus drawn and submitted, a bill is in the best possible form, and there is no possibility of its being made the instrument for the enactment of what are commonly called "jokers."

Bills thus drawn may not be perfect, for no human work is perfect, but they will be much better drawn than the great majority of bills presented to a legislature; and, if adopted, will be an improvement upon legislation already in force on the same subjects. The people of a state will never vote against their own interests, hence they will never vote to adopt a law unless it proposes a change for the improvement of the general welfare. Previous to the last election, each voter had fifty-five days in which to consider thirty-two measures, which, with the arguments for and against, were laid before him in convenient printed form. This gave him an average of nearly two days for the consideration of each measure. Assuming that many of the bills introduced in one house never appear in the other, each member of the Oregon Legislature was called upon to consider about five hundred bills in forty days, or over twelve each day, besides being compelled to consider many resolutions, motions, and questions of a political character. In my opinion, the individual voters of the state, in the quiet of their own homes in the evening, could better consider and decide upon an average of one bill in two days than the members of the legislature, amid the hurry and strife and personal feeling incident to a legislative session, could consider and decide upon an average of twelve bills a day. It is erroneous to assume that the voter is required to pass upon a large number of measures in the few minutes he occupies the booth on election day. Such is not the case. He has several weeks in which to determine how he will vote, and merely takes a few minutes in which to mark his ballot.

\section{To Educate and Develop the People}

I have thus indicated the second function of the initiative and referendum-to educate and develop the people. Establishment 
of direct legislation places upon the people responsibility for all legislation, for, having power to enact or defeat any law, they must be responsible for that which exists. When the people fully understand and realize this responsibility, they study their government more carefully and take deeper interest in the administration of its affairs. Where the initiative and referendum do not exist, the people have little encouragement to devote time and effort to the study of public questions, for, even if they desired, they have no power to change laws or conditions. Therefore, chief among the advantages of the initiative and referendum is the unlimited field afforded for individual and community development. Direct legislation establishes equal opportunity in government, for it places in the hands of every man the same machinery for accomplishment that every other man enjoys. It opens the way for men of good ideas and enables the whole community to secure the advantages arising from advanced thought.

Suppression of the individual is one of the results of delegated government; development of the individual necessarily follows adoption of popular government. Suppression of the individual is seen in every convention and every legislative body-city, state and national.

The great masses of the people are always more advanced in thought and ideals than a majority of men who secure positions of power in conventions or legislative halls. This has been demonstrated in numerous instances, which will readily suggest themselves to the minds of readers of this assertion. For instance, throughout the United States there is an overwhelming public opinion, carefully formed, in favor of popular election of United States senators. That opinion has existed in the minds of the people for a decade or more; yet party conventions have failed to endorse the principle and congress failed until recently to submit an amendment to the constitution in accordance with the popular will. The people of the country realize that no man can be elected United States senator by an uninstructed legislature unless he knows the individual members to whom he is primarily obligated for his election, and, what is still worse, in many instances, unless he knows the political boss, campaign contributor or special interest dominating a number of legislative members sufficient to prevent his election unless there is agreement, express or implied, to favor and protect with national 
legislation the dominant interest. The people of the country have long desired to destroy this obligation to individuals and substitute therefor an obligation to the composite citizen; but a majority of members of the senate have only recently advanced to this idea of governmental accountability.

Always there are a few intellectual leaders who are in advance of the masses of the people; but the practical workings of delegated government are such that the masses of the people are always in advance of those individuals who secure political but not intellectual leadership. "Practical politics," under a system of delegated government, brings into power men who are guided more by selfish interest than by general welfare. Popular government reverses this condition and gives power to intellectual leaders rather than to men whose success is due to skill as "practical politicians."

Occasionally there arises a man who is not only an intellectual leader but also a practical politician of such ability as to secure adoption of his ideas, even under a system of delegated government; but these instances are rare. Though working with tine old tools of government, an intellectual leader in Wisconsin was able to secure practical adoption of many of his ideas. Greater and earlier success would have attended his efforts if direct legislation had afforded him a means of appealing direct to the people of his state.

\section{The Instrument of Intellectual Leadership}

The power of direct legislation under the initiative and referendum is the practical machinery of intellectual leadership. Without that machinery the intellectual leader is in most cases powerless. How often have we seen this illustrated in conventions and legislatures. Occasionally a man with advanced ideas secures a seat in a party convention, though usually men of that kind are not wanted by the leaders who make slates of delegates; but when the man of originality and progress gets into a convention he finds himself powerless. If he wishes his party to incorporate in its platform a plank embodying an advanced principle in government he formulates a resolution for that purpose; and, under the rules, that resolution goes to a committee without having been read to the convention. The committee have been carefully selected in advance after consultation among men who, because of their skill in "practical politics," are able to manipulate conventions. Members of the com- 
mittee know the men to whom they owe their selection and the interests back of the organization. Their action upon the resolution submitted by the progressive delegates is, therefore, in accordance with the wishes of the interest they represent; and when the party platform is read it contains no endorsement of the new idea unless popular demand has forced its adoption. A convention is less progressive than the people; a committee on resolutions is less progessive than a convention; hence the strangulation of new ideas in a convention.

Legislatures that, in theory, represent the people, generally prove to be less advanced in thought than the people themselves. Though legislators are elected by the people, they are in most states nominated by conventions controlled by "practical politicians" backed by campaign contributors. Hence members of a legislature feel an obligation to certain known individuals and their first act is to co-operate with those individuals in the organization of the legislature. This organization includes the appointment of standing committees, which appointments are usually made after consultation with the same "practical politicians" who controlled the nominating conventions, with the result that important committees are so constituted as to make protection of special interests certain. Then, when the legislator with advanced ideas introduces a bill for promotion of the general welfare as against special interest, the bill goes to a committee representing special interest and there remains until the close of the session; or, if reported at all, comes to light too late for action or with amendments that change its character. This procedure has been witnessed in every legislature in every state. Applying to a legislature the statement in the last preceding paragraph, a legislature is less progressive than the people; a "graveyard committee" is less progressive than a legislature; hence the strangulation of new ideas in a legislative body.

On the other hand, direct legislation encourages individual development. Under the initiative any man can secure the submission of his ideas to a vote of all the people, provided eight per cent of the people sign a petition asking that the measure he proposes be so submitted. There is no opportunity for secret strangulation and all the people have the advantage of studying the ideas of the most advanced, and have opportunity to adopt those ideas if they deem such action wise. 


\section{Promotes the General Welfare}

This unlimited opportunity for individual accomplishment opens the way for legislation for the general welfare, and, as I view it, only legislation for the general welfare can secure popular endorsement. This opinion is founded upon an analysis of the forces controlling human action. Either impulse or deduction, followed by conviction, controls all human action. If the individual be confronted with the necessity for immediate action, then impulse arising from emotion, such as love, hatred, anger, sympathy, sentiment, or appetite, is the determining force. Without conviction there will be no action.

Individual action should be guided by reason, but is frequently emotional. Community action, as in an election, must be based upon conviction resulting from analysis and deduction. Self-interest is the force controlling every future or postponed action of the individual, not necessarily always selfish interest, for sometimes the individual is satisfied with his participation in the improved general welfare incident to the action. Generally, however, the individual's action, when unrestrained, is governed by his own selfish and personal interest.

No two people in the world are exactly alike; consequently each individual has a different point of view or idea as to what constitutes his own particular personal or selfish interest. Where individuals act collectively or as a community, as they must under the initiative, referendum and recall, an infinite number of different forces are set in motion, most of them selfish, each struggling for supremacy, but all different because of the differences in the personal equations of the different individuals constituting the community. Because of their difference, friction is created, each different selfish interest attacks the others because of its difference. No one selfish interest is powerful enough to overcome all the others; they must wear each other away until general welfare, according to the views of the majority acting, is substituted for the individual selfish interest.

If all the individual units of society were alike, then selfishness would dominate not only the individual but the community action as well. But so long as no two people are alike, just so long will selfishness dominate the individual if permitted to act independently, while general welfare must control all community action; for if the individual can not secure the gratification of his own selfish desire, 
then he must rest satisfied with the improved general welfare in which he, as one of the units of the community, is a proportional participant.

This logic applies to a community or a class. Under the initiative, referendum, and recall there can be no class or community action against the general welfare of the citizens constituting the zone of action. The individual, through realization of the impossibility of securing special legislation for himself and against the general welfare of the community, soon ceases his efforts for special privilege and contents himself with efforts for improved general welfare. Thus the individual, class, and community develop along lines of general welfare rather than along lines of selfish interest.

In further refutation of the unwarranted fear of hasty or unwise community action, I assert that no individual will ever vote for, or willingly assent to, a change, unless satisfied that that change will directly benefit him individually, or that the action will bring improved general welfare to the community, in which event he is satisfied with proportional participation incident to that improvement. In other words, community action determines the average of individual interests, and secures the greatest good for the greatest number, which is the desideratum of organized society.

\section{Prevents Special Legislation}

As a preventive of legislation against general welfare, the referendum operates in two ways. First, it discourages the passage of such measures by a legislature through realization that the people can and probably will defeat the same under the referendum. Second, if such legislation be passed either intentionally or through ignorance of its effect, the people can and will invoke the referendum power and thus prevent its becoming effective.

\section{Eliminates Legislative Blackmailer}

One of the most contemptible enemies of society is the legislative blackmailer - a member of a legislative body who introduces a bill unjustly attacking some business interest with no honest intent but for the purpose of inducing the threatened interests to pay for the abandonment of the measure proposed. A public servant vested with legislative power who thus violates his trust not only injures a private interest but brings the powers of government into contempt. 
Only physical courage is lacking to make such a man a highwayman or a pirate. His operations are the more dangerous because difficult to prove. The referendum affords a remedy, however, because any interest unjustly attacked in this manner can safely refuse to buy immunity or pay tribute, and, if the unjust bills be passed, can appeal to the people under the referendum, confident that the people will not give their approval to such legislation. Corporations in Oregon have not been held up with "pinch bills" since the initiative and referendum became effective in that state.

\section{Developing Infuence on Legislators}

The initiative and referendum also develop legislators by causing them in their deliberations to keep always in mind the interests and viewpoint of the people whose servants they are. This they will do through a realization that, having power to enact or defeat laws, the people. will watch legislative proceedings and hold every legislator accountable for his acts. Under the referendum corruption of members of the legislature is practically eliminated because of the knowledge on the part of the persons desiring special legislation that even though enacted by the legislature, defeat of such laws is within the power' of the people.

\section{The Recall Chiefly Admonitory}

The recall, to my mind, is rather an admonitory or precautionary measure, the existence of which will prevent the necessity for its use. At rare intervals there may be occasion for exercise of the recall against municipal or county officers, but $I$ believe the fact of its existence will prevent need for its use against the higher officials. It is, however, an essential feature of a complete system of popular government and $I$ see no reason why a man who occupies a judicial position should be governed by laws or standards of public service different from those which apply to legislative or executive officers. Judges are but human. We sometimes elect legislators to the bench, send former judges to the legislature, and place judges in executive positions, even elevating them to the highest executive office in the land. Does a man change his standards of ethics when he changes his office? I think not. A man who is dishonest or incompetent in an executive or legislative office will as likely be dishonest or incompetent in a judicial office. A man who would use his power 
as an executive in an improper manner or for improper purposes would exercise judicial power in the same way. In any branch of the government he is a servant of the people, not their master; and he should be subject to dismissal by the people after fair opportunity to be heard upon his record.

To assert that judges are above corruption or improper prejudice and that they are always efficient public servants is too absurd for serious consideration. The men who sit on the bench to-day were boys when members of the legislative and executive branches of government were boys. They were no better or worse on the average. In childhood and young manhood they mingled on an equality, enjoyed the same sports, received instructions in the same schools, were taught the same religious principles, were subjected to the same temptations, indulged in the same vices, and cherished the same ambitions. Upon what reasoning, then, can it be asserted that the boy who studied law and found such favor in the eyes of the political boss as to secure a nomination for the bench is superior in either efficiency or honesty to his brother who entered business and was slated by the same boss for a position in the executive or legislative branch of government?

There hangs no halo of sanctity around the head of the judiciary, except as unthinking men concede a sacredness which the legal profession has assumed for occupants of the bench. Judges, like all other men in public or private life, are generally honest. Their failure, in exceptional instances, to serve faithfully the people by whom they are employed, is due to the same cause to which may be attributed similar failure on the part of other public servants. This cause is largely the unrepresentative system by which they are chosen.

Adoption of the recall is nothing more than the application of good business principles to government affairs. Every wise employer reserves the right to discharge an employee whenever the service rendered is unsatisfactory. The right of the employer to discharge his employee rests upon exactly the same basis as the right of the employee to quit. The principle is recognized throughout the business world, and it is put in practice by every large and successful corporation.

Consider the absurdity of the recognition of the right of a public officer to quit his position at any time and the denial of the right 
of his employers to discharge him. To assert the right in one instance and deny it in the other is to maintain a one-sided contract, the discrimination being against the whole people and in favor of the individual. If we can trust an individual to deal justly with the people when he considers tendering his resignation, we can also trust the people to deal justly with a public servant when they consider discharging him.

It is generally conceded that the American people have intelligence and honesty enough to be trusted with the power to select their public servants, even to choose a President of the United States. If it be granted that the people have intelligence enough to choose a President of the United States, no man can consistently contend that they have not the intelligence to act wisely upon the question of discharging a state, county, or municipal officer. I think no one proposes, at present, to extend the recall to any federal official except those elected by tha people of the several states.

All that is desired by the people of any state, county, or city is good service for the general welfare. They will never make a change unless satisfied that it will be a change for the better, hence they will never discharge a public servant unless convinced that his successor will be a more faithful and more efficient public official. They have a right to improve their government, or try to do so, if they see an opportunity, and this is the function of the recall. The interests of one individual must not stand in the way of better government.

We have heard much about the "rule of the mob" in connection with the initiative and referendum and the recall. A mob is a body of men acting against law, order, and justice. Iegislatures sometimes do this-the people never, if given an opportunity to act in a lawful way. I grant that where wrongs have been long imposed and remedies have been denied, the people finally resort to force to redress their grievances, just as they did in the American Revolution. Resort to force came only after every peaceful means had been tried in vain and when longer endurance was impossible.

To some this is mob action. I am disposed to give it a higher characterization; and though it is an overthrow of existing authority, I regard it as the establishment of law and order in the highest sense. When the people of a republic, exercising their inherent right to change their laws and constitutions, vote to adopt new and better systems 
of government, I deny that this is mob action; it is the establishment of law and order. The overthrow of a misrepresentative system, maintained by political machines enjoying dictatorial powers, and the substitution of a truly representative system means the attainment of higher standards of human justice and equality, and, consequently, of a more peaceful and more nearly perfect government. The voice of the people should be the law of the land, and, since the initiative and referendum and the recall register the voice of the people, they are the best mediums for the establishment of the best governmental principles.

Adoption of the initiative, referendum and recall is in entire accord with the principles on which our government was founded. The most intellectual, most courageous and most patriotic of the American people in 1776 declared that governments derive their just powers from the consent of the governed, and that it is the right of the people to alter or abolish their form of government and to institute new government, laying its foundation on such principles and organizing its powers in such form as to them may seem most likely to effect their safety and happiness. Years of experience with legislatures chosen by special interests and executive administrations wielding patronage powers sufficient to force re-nomination, have convinced the American people that there is need for the initiative and referendum in the several states and for the other popular government laws, the direct primary, efficient corrupt practices act, recall, and, nationally, a presidential preference law which will destroy the power of an administration to perpetuate itself in office or dictate the selection of its successor. The possession of the powers comprehended by these laws is sovereignty and the restoration of popular sovereignty is the chief function of the initiative, referendum and recall. 